\title{
POSSIBILITIES FOR THE USE OF INFORMATION OBTAINED BY USING INFORMATION AND TECHNICAL MEANS AND MEANS OF OPERATIVE-SEARCH ACTIVITIES IN OTHER CRIMINAL MATTERS ${ }^{4}$
}

\author{
Zuzana KURUCOVÁ \\ Institute of Theory and History of state and socio-science disciplines, Faculty of Law PEU
}

\begin{abstract}
ANNOTATION
Information that were obtained legally using information and technical means and means of operative-search activities have the nature of evidence in criminal proceedings. The nature of evidence is granted directly to this information, not to the media where they are recorded. In the case of legal use, this information has the nature of evidence in the criminal case, but the provisions of Criminal Procedure Code in the Slovak Republic contribute significantly to the detection and proving of serious criminal offences, because such information can be indirectly used also in other criminal case. Problematic is the fact that the Supreme Court of the Slovak Republic adopted differing positions precisely on these options of the use of evidence in other criminal case, this dispute was also joined by the Prosecutor's office and this application problem has not been resolved even by the unifying opinion at the level of the Supreme Court of the Slovak Republic. There is therefore still an open question from the point of argumentation and application, what evidence can be used also in other criminal cases or under what conditions.
\end{abstract}

\section{KEY WORDS}

information, evidence, con-current conduction of criminal prosecution, application practice.

\section{JEL CLASSIFICATION}

K14, K20, K30.

\section{INTRODUCTION}

Detection and proving of serious crimes or serious types of crimes was only a little effective by the use of classic detection institutes in recent years. Sophisticated forms and methods of committing criminal offences also direct the law enforcement authorities to use modern, offensive means for their detection and proving, but these intensively intervene in the area of guaranteed rights. Using these means, especially the information and technical means, as well as the means of operativesearch activities may be assessed as absolutely necessary in the process of detection and proving of many criminal offences. Their detection and proving by means of other typical evidence is

\footnotetext{
${ }^{4}$ This study was supported by the Agency for the promotion of research and development on the basis of the Contract No. APVV-16-0521
} 
considerably complicated and in most cases unsuccessful exactly with respect to the specific features of advanced forms of criminality. Probative misery is typical for the detection and the process of taking evidence; several standards of evidence and means of evidence cannot be used in the process of taking evidence (witness statements, if witnesses are absent) and the significance of evidence of some other is or may be relatively low (examinations of informants, intermediaries, the accused). Often, even persons who in some way know about committed crimes, are afraid to report it for fear of potential threats to themselves or their relatives. ${ }^{5}$ The often fear to make a statement because of fear of possible criminal prosecution. It often happens that they prefer to state that they know nothing about that crime, they did not see or hear anything, rather than speaking openly, fully and truthfully about the facts they know. Persons taking directly or indirectly part in criminal activity or involved in it in any way, in turn, are not interested that their activity was discovered and that their substance was revealed. ${ }^{6}$ Many information that would potentially be important for criminal proceedings are, moreover, covered by legal protection in the form of protection of personal data, protection of legally protected secrets and it is not possible to obtain them in a standard way. Of course, one can see here the clash with a range of individual rights. ${ }^{7}$ The evidence obtained with the aid of information and technical means (the "ITP"), as well as the means of operative-search activities (the "OSA") helps to get over this considerably complicated situation. The options of evidence use in other criminal case laid down by law at the present also allow to get over this, if these were obtained legally in the original criminal case.

\section{EVIDENCE OBTAINED BY ITP AND OSA}

In both cases, in ITP as well as OSA, it is important to state that these means are implemented directly on the basis of legal provisions by covert manner so that the persons concerned are not at the time and place aware that they are being used. If they had the knowledge, as a general rule, they would adjust their action so that no facts showing their unlawful and criminally relevant action was revealed. The intensity of intervention may also be seen here, as in the case of these sources. Therefore, it is important to ensure consistent compliance with basic legal requirements of their use, so that they could be pronounced legal, and this also within the meaning of our regulation, as well as within the meaning of the Convention on the protection of human rights and fundamental freedoms.

Rapporteur method of these means (most of them) allows to obtain objective knowledge not influenced by interests of the participated subject, and the knowledge is very important in the process of taking evidence. ${ }^{8}$ The evidence obtained using information and technical means and means of operative-search activities have the nature of direct evidence in criminal proceedings, whether information or things in the form of real evidence. ${ }^{9}$ Yet the most often used information was obtained (legally) by using information and technical means (mainly by tapping and records of telecommunications and taking of video, audio or video/audio recordings) and also information and things that were obtained (legally) by using operative-search activities (as tracking people and things, agent, controlled delivery or even a pretended transfer). With regard to the taking of evidence, this is done by law enforcement bodies in the pre-trial process and by the parties to the proceeding who proposed the individual evidence in the proceedings before the court. Real

\footnotetext{
${ }^{5}$ Kyjac, Z.: Použitie informačno-technických prostriedkov v trestnom konaní. Bratislava: Wolters Kluwer, 2015 , p. 62 et seq.

${ }^{6}$ Tittlová, M.: Zákon o ochrane súkromia pred odpočúvaním. Comment. Bratislava: Wolters Kluwer, 2017 , p. 31 et seq.

${ }^{7}$ Skorková, V., Kotrecová, A.: Vplyv judikatúry ESLP na rozhodovanie vnútroštátnych súdov vo veciach práva na ochranu súkromia. In: Acta Iuridica Olomucensia, No. 8/2013, p. 129

${ }^{8}$ Ivor, J., Polák, P., Záhora, J.: Criminal Procedure Code. II ${ }^{\text {nd }}$ part. Bratislava: Wolters Kluwer, 2017, p. 216 et seq.

${ }^{9}$ Ivor, J., Tóthová, M.: Informácie získané použitím informačno-technických prostriedkov a prostriedkov operatívnopátracej činnosti. In Ivor, et al.: From crime to punishment. Bratislava: EUROKÓDEX, 2012, p. 141 et seq.
} 
evidence shall be taken by submission and inspection, examination by parties and where appropriate, these shall be submitted for inspection to witnesses and experts. Documentary evidence shall also be submitted for inspection and it shall be possible to consult their content. Audio, video or audio/video recordings are taken as evidence on technical equipment, namely by consulting their entire content or their part, which concerns or is in some way related to the fact to be proven in a way linked to the established fact ( $§ 270 \mathrm{CPC}-$ Criminal Procedure Code). If this is due to the nature of evidence, it is also possible to take evidence by consulting their entire written transcription or part of this transcription, which relates to the proven fact.

Various aspects of criminal activity and the agreement or communication, may also be communicated through the telecommunications service. It can be information on the object of crime, on certain acts, provided performances, place, and time of the relevant persons involved in criminal activity, etc. It is often possible to obtain such knowledge by tracking people and things in criminal proceedings, or by making video, audio and video/audio recordings in criminal proceedings.

Legal use of these institutes leads to the finding of facts important for criminal proceedings; and this information has the nature of evidence in criminal proceedings. It is the use of this institute in the framework of criminal proceedings and on the grounds of the criminal procedural provisions. This fact must be pointed out that it is the procedural use of these sources. The nature of evidence is also granted to information obtained by making use of this institute outside the context of criminal proceedings, on the grounds of special regulations (e.g. the Act on protection of privacy before tapping ${ }^{10}$ ). If facts are discovered outside the scope of the proceedings that are important for criminal proceedings these can be used as evidence therein. Such a possibility of use does not exist in the Czech Republic for example ${ }^{11}$; however in Slovakia it is possible, because directly $\S 119(2)$ CPC states that everything that is directed to proper clarification of things and was obtained on the grounds of the Criminal Procedure Code or under a special regulation can be used as evidence. This last part - special regulation - subsumes for us the possibilities of indirect use of evidence obtained outside the procedural rules in the criminal proceedings, at the procedural level (indirect use). ${ }^{12}$

In order to use the information thus obtained as evidence in criminal proceedings, it is necessary that the person who was tapping and recording, tracking, or producing records made a written record containing the data on the place, time and legality of the use of this means, and attached the literal transcription to such a record. Only information that is covered by reasons for use of this means in the application and reflected in the disclosed order can be used as evidence. Other evidence cannot be used in the criminal proceedings.

In accordance with the provisions of $\S 113(8) \mathrm{CPC}$ and $\S 114(6) \mathrm{CPC}$, which also refer to the provisions of $\S 115(6) \mathrm{CPC}$, where information obtained by using these means on the grounds of $\S$ 113 through to $\S 115 \mathrm{CPC}$ is to be used in criminal proceedings as evidence, it is necessary to make their transcript within the scope of facts significant for criminal proceedings, if it is allowed by the nature of the record. The transcription is not made of whole hours, weeks or months of records, but only those facts are transcribed that are important for criminal proceedings. Transcripts shall be carried out by members of Police forces, who took these means or provide real tracking, tapping, and drafting of records. At the same time, it is necessary to state all data on place and time of the activity, who carried out this work and the data on the legality of these means. The transcription made in this way is put to file and is no longer subject to confidentiality. It could be subject to confidentiality, only if it included facts that are protected under special regulations as secrets

\footnotetext{
${ }^{10}$ Tittlová, M.: Zákon o ochrane súkromia pred odpočúvaním. Comment. Bratislava: Wolters Kluwer, 2017, p. 23 et seq.

${ }^{11}$ Ruling of the Constitutional Court of the Czech Republic I. US 3038/07

12 Tittlová, M.: Zákon o ochrane súkromia pred odpočúvaním. Comment. Bratislava: Wolters Kluwer, 2017, p. 62
} 
defined by law. The record is also kept on an appropriate data medium directly in the dossier, and therefore it is available for possible making of copies (they are also important with a view to possible correction procedure). The defendant and defence attorney may request transcripts to the extent considered to be appropriate and necessary on their own costs, but of course, only after the end of tapping activity. In general, the information that was obtained legally by using this means can be used as evidence in criminal proceedings only after the activity was finished. Before, i.e. during real use of these means, it is not possible to use such information as evidence. It is also not possible to use the information as evidence that was obtained by tapping, tracking or recording activity, if it is communication between the defendant and the defence attorney on such matters, where the defence attorney represents the defendant in criminal proceedings.

\section{USE OF EVIDENCE IN OTHER CRIMINAL CASE}

On the grounds of provisions in $\S 113(9), \S 114(7)$ and $\S 115(7)$ CPC, information obtained by using the information and technical means can be used both in the proceedings in which the use of means was directed, but it is also possible to use it in other criminal case on condition that also in this other criminal case the criminal prosecution is held con-currently for such a criminal offence for which it is possible to use this means in criminal proceedings (§ 113(1) CPC , § 114(1) CPC and $\S 115(1) \mathrm{CPC}$ ). If the information thus obtained is to be used as evidence also in other criminal case, the criminal prosecution must also be conducted con-currently for some of the identified criminal offences in this criminal case. The purpose and nature of this provision is to facilitate the taking of evidence in the most serious criminal offences so that the evidence obtained in one criminal case could be "indirectly" also used in other criminal case, if there is also criminal prosecution conducted (first procedural condition) and if it is a proceeding for offences where the use of the means is possible (second condition of substantive law). Though the second condition, i.e. the list of criminal offences in that the criminal prosecution is conducted also in the second criminal case does not cause any problems in the application practice, the first condition is very controversial. It is disputed to which moment the requirement of con-current conduction of criminal prosecution relates. This condition may be applied to the moment when the information and technical means are being used, i.e. the moment when the tapping is actually done and telecommunication connection recorded, or to the moment when the records obtained by the use of this means are being used, i.e. when information obtained from them are being used as evidence. The criminal procedural provisions of the Criminal Procedure Code neither solve this problem explicitly, nor offer specific instruction how to clearly resolve this problem. It is interesting that the use of such records also in other case shall be conditional on any such request - condition of concurrent conduction of criminal prosecution also in other criminal case. This is interesting because at the non-procedural level, i.e. where the legislation should be a bit more stringent and exact, since it is outside the context of criminal proceedings, and therefore there is no criminal complaint filed, criminal prosecution initiated or a charge being made, at this non-procedural level there are no such restrictions stipulated for usability of evidence. If facts important for criminal proceedings and obtained through information and technical means are used outside the context of criminal proceedings on the grounds of specific regulations, these can be used in criminal proceedings as evidence. There is no condition expressed that at the time of use of these means or until the end and during the time of use of records obtained from them, there had to be a criminal prosecution conducted in the criminal case. Therefore, at the non-procedural level, where the regulation for the use of such evidence should be even stricter, there are no such restrictions, while at the procedural level, i.e. upon existence of suspicion ensuing from criminal complaint or after the initiation of a criminal prosecution and, where appropriate, also after bringing of charges, this condition or restriction is stipulated. Therefore, where such restrictions with regard to the level of use, should exist, they do not, and where they did not need to be they are stipulated. Naturally, this regulation is both illogical and then in any case inharmonious. The rights of persons in criminal proceedings in a 
certain position (a suspect or a defendant) are protected to a higher degree then the rights of persons, who are not in such a criminal procedural position.

The purpose of provisions in $\S 113(9), \S 114(7)$ and $\S 115(7)$ CPC is to facilitate taking of evidence in selected criminal offences for which these means may be ordered. It is exactly the condition of con-current conduction of criminal prosecution also in other criminal case which is disputed, and which limits its applicability to a significant degree. The fact that it is not quite clear to which moment the con-current conduction of criminal prosecution in the other criminal case relates also provoked discussions on this issue and that without a clear conclusion. Different criminal boards of the Supreme Court of the Slovak Republic (SC SR) failed to agree on solution of this problem within their decision-making activities. One criminal senate of the SC SR relates the condition of con-current conduction of criminal prosecution also in other criminal case to a moment when the results of tapping and record of telecommunication connection are used, not the moment of use of these means, and the second criminal senate of the SC SR interpreted that condition exactly in the opposite way. The senate of the SC SR directly stated that it would be illogical, if the record obtained by legal tapping in a case where the use of such means had been ordered (and this also in the time even prior to the commencement of prosecution, i.e. in the procedure prior to the commencement of prosecution) could only be used in a criminal case under the condition that already at the time of tapping there would have to be a prosecution initiated in other criminal case. If we insisted on the condition that there had to be a criminal prosecution initiated where the evidence is to be used already at the time when the tapping and record of telecommunication connection was made, this would be illogical. Nothing would prevent to issue an order for legal use of this means also in this other criminal case and it would not be necessary to use the evidence obtained indirectly in other criminal case. If we interpreted the condition for con-current conduction of criminal prosecution in the opposite way, it would also limit the usability of provisions in $\S$ $113(9), \S 114(7)$ and $\S 115(7)$ CPC to a minimum, if at all to some cases and naturally, this is not the purpose and nature of this provision ${ }^{13}$. This would not help the taking of evidence also in other criminal offences for which that means may be ordered (its use may be ordered), and this was most probably the intention of the legislator when creating the provision in question. This decision therefore applies to the condition for con-current criminal prosecution also in other criminal case to the moment of records use, or the use of information obtained by the means (legal use).

On the other hand, there is the opinion of other senate of the Supreme Court of the Slovak Republic $^{14}$ and it states that the condition of con-current conduction of criminal prosecution should relate to the moment when tapping and the record of telecommunication connection were made. It directly states that under the con-current conduction of criminal prosecution also in other criminal case it is necessary to understand the action, decision or other procedure taken on the basis of CPC, which in other criminal case happened before obtaining the probative information on the matter in which that procedure was ordered (its obtaining, tracking of people and things by video, audio, video/audio recording, tapping and records of telecommunication connection, through an agent or by comparing data in the information systems).

Coincidence in time of two criminal cases and criminal prosecutions in the cases, namely in the moment when the probative information to be used also in the other criminal case (i.e. in duplicate), is considered to be decisive. It is not possible to put the factual relationship to the foreground, this was also stated by the criminal senate of the SC SR in its ruling of February 2012. The Senate of the SC SR has refused the finding of the first instance court here, which related the con-current conduction of criminal prosecution in the other case to the moment of use of records obtained in this way (or information from them as evidence in criminal prosecution). According to the senate of SC SR, the court of first instance was wrong here. "It does not correspond to material logic that the

13 Ruling of the Supreme Court of the Slovak Republic 3 To 2/2011 of 21 September 2011

${ }^{14}$ Ruling of the Supreme Court of the Slovak Republic 2 To 5/2011 of 07 February 2012 
law required con-current conduction of criminal prosecution in the case as a condition for probative usability of information, if the information was obtained legally in the case and the con-currency of proceedings should have been given at the time, when the information was used in other criminal prosecution (that is, in the end, sometimes first only at the main hearing of court proceedings). ${ }^{15}$

\section{CONCLUSION}

On the basis of this brief outline, it can be seen that the criminal procedural regulation does not clearly solve the moment related to the condition of con-current criminal prosecution in other criminal case. Interpretation of this condition is therefore difficult and, in particular, allows to take different positions, as is shown by the various decisions of various boards of the SC SR, where one of them was supported also by the opinion of PO SR (Prosecutor's Office of the Slovak Republic). Within the possibility of the SC SR to adopt unifying opinions aimed at uniform application and interpretation of the provisions of legislation, the collegium of the SC SR tried to adopt a unifying opinion also in this case. However, it supported the conclusion contained in the opinion of PO SR and at the same time in the ruling of the SC SR of February 2012 in its proposal. But in the end, the unifying opinion on this matter wasn't adopted and so it was recommended to the legislator to solve this problem at the legislative level. Despite this, until today it did not happen, and it is not a young application problem at all.

It can only be recommended that the provisions in question were amended, and the possible solutions are several. The first leads toward a clear interpretation and purpose of the controversial condition and the provision in question. Its purpose is to help in taking of evidence in criminal offences, where it is possible to order the use of this institute. Therefore it is illogical that this option was complicated by setting of nonsensical conditions and restrictions. There is no such condition stipulated at the non-procedural level that should be even stricter in terms of protection, however. By following the example of this non-procedural regulation, the condition of con-current criminal prosecution in other criminal case should be removed from this provision (this is the second possible solution to this problem). Or the provisions of $\S 113(9), \S 114(7)$ and $\S 115(7)$ CPC should be supplemented by an explanatory statement that the con-current criminal prosecution in the other criminal case is linked to the moment of using the outputs obtained by these means, i.e. to the moment of using the obtained records as evidence. It would be illogical that criminal prosecution also in the other case had to be conducted already at the time when the information and technical means and the means of operative-search activities were carried out, as in that time it could be already achieved in the second criminal proceeding or prosecution by issuance of such an order. Such information wouldn't have to be used indirectly. In addition, if within one criminal case certain facts are found within the scope of particular information-technical means, this is as a general rule in their nature unique information, therefore it is possible to state and rather incline to the conclusion and opinion that with the exception of substantive scope of the institute, the option of indirect use of evidence also in the other criminal case should not be restricted at all.

\section{REFERENCES}

Ivor, J., Polák, P., Záhora, J.: Criminal Procedure Code. II ${ }^{\text {nd }}$ part. Bratislava: Wolters Kluwer, 2017. Ivor, J., Tóthová, M.: Informácie získané použitím informačno-technických prostriedkov a prostriedkov operatívno-pátracej činnosti. In Ivor, et al.: From crime to punishment. Bratislava: EUROKÓDEX, 2012.

Kyjac, Z.: Použitie informačno-technických prostriedkov v trestnom konaní. Bratislava: Wolters Kluwer, 2015.

\footnotetext{
${ }^{15}$ Ruling of the Supreme Court of the Slovak Republic 2 To 5/2011 of 07 February 2012, p. 17 and 18
} 
Skorková, V., Kotrecová, A.: Vplyv judikatúry ESLP na rozhodovanie vnútroštátnych súdov vo veciach práva na ochranu súkromia. In: Acta Iuridica Olomucensia, No. 8/2013.

Tittlová, M.: Zákon o ochrane súkromia pred odpočúvaním. Comment. Bratislava: Wolters Kluwer, 2017.

Criminal Procedure Code (Act No. 301/2005 Coll., as amended).

Ruling of the Constitutional Court of the Czech Republic I. US 3038/07.

Ruling of the Supreme Court of the Slovak Republic 3 To 2/2011 of 21 September 2011.

Ruling of the Supreme Court of the Slovak Republic 2 To 5/2011 of 07 February 2012. 